\title{
Knowledge And Attitude On Mental Illness Among People Of A Selected Community Of Biratnagar
}

\author{
Jha P1, Mandal PK ${ }^{2}$ \\ 1. Registered Nurse, Department of Health Service, Government of Nepal, Matihani Health post, \\ Mahottari, Nepal 2. Instructor, Nursing Department, Tribhuvan University Institute of \\ Medicine, Biratnagar Nursing campus, Biratnagar Nepal
}

E-mail *Corresponding author : poomandal@ gmail.com

\begin{abstract}
Introduction: Mental disorders are widely recognized as a major contributor to the global burden of disease. Mental illness often generates misunderstanding, prejudice, confusion and fear; therefore it should be a concern for all of us, rather than only for those who suffer from a mental disorder. Aim of this study is to assess the knowledge and attitude on mental illness among people of a selected community.
\end{abstract}

Material And Method: Descriptive cross-sectional research design was used to assess knowledge and attitude in selected community of Biratnagar. Sample size was 92. Non-probability purposive sampling technique was used to collect data through face to face interview using Semi-structured questionnaire. Data entry and analysis was done on SPSS version 16.Descriptive statistics was calculated.

Results: Finding of the study shows $88 \%$ views mental illness as a medical condition. All respondents identified that mentally ill people cannot held his/her responsibility and are prone to violent. Mental illness perceived as treatable by $66.7 \%$ with regular treatment and follow-up and $20.7 \%$ preferred treatment with traditional healer. Findings of the study showed adequate level of knowledge among $97.8 \%$ respondents.

Conclusion: The finding of the study suggests level of knowledge was adequate among respondents whereas most of them had negative attitude towards mental illness. The level of negative attitude suggests the strong emphasis on public education towards mental illness.

Keywords: Mental illness, Knowledge, Attitude, Common People

\section{INTRODUCTION}

Mental illnesses are health conditions involving changes in thinking, emotion or behavior (or a combination of these). Mental illnesses are associated with distress and/or problems functioning in social, work or family activities. ${ }^{1}$ Mental illness is any defined disease or condition affecting the brain that influences the way a person thinks, feels, behaves and relates to others, and to his surroundings. ${ }^{2}$

In most parts of the world, mental health and mental illness are largely ignored or neglected, resulting in increasing burden of mental disorders in the community and a widening of "treatment gap". ${ }^{3}$ A network of most of the organizations working in the mental health and psychosocial fields has also been established for policy advocacy. Lack of financial resources, low mental health literacy, misconceptions and stigma associated with mental health problems, contribute to delay access to treatment. In addition, poverty, conflict, displacement and discrimination based on gender and caste/ethnicity, unemployment, and (labor) migration are found to be key risk factors for poor mental health in Nepal .4 Mental illness often generates misunderstanding, prejudice, confusion and fear therefore it should be a concern for all of us, rather than only for those who suffer from a mental disorder. Of all the health problems, mental illnesses are poorly understood by the general public. Such poor knowledge and negative attitude towards mental illness threatens the effectiveness of patient care and rehabilitation. ${ }^{5}$ 
Mental Health is $5^{\text {th }}$ leading cause of all DALYs $(7.4 \%)$ worldwide. The global burden of mental illness projected to rise above $\$ 6$ trillion by 2030 . 6 A report stated that $31.7 \%$ of all years livedwith-disability to neuropsychiatric conditions: the five major contributors were unipolar depression (11.8\%), alcohol-use disorder (3.3\%), schizophrenia $(2.8 \%)$, bipolar depression $(2.4 \%)$, and dementia (1.6\%). ${ }^{7}$

Misunderstanding and stigma surroundings mental ill health are widespread. Despite the existence of effective treatments for mental disorders, there is a belief that they are untreatable. ${ }^{8}$ Kohrt and Harper, explained that "Addressing the social stigma of mental illness in Nepal requires an understanding of local mind-body divisions. ${ }^{9}$ whereas, a study showed overall level of discrimination across the life areas studied has fallen over 2008-2012, there is no evidence that more people using mental health services experience no discrimination. ${ }^{10}$ Lack of public awareness is a potent barrier for the early detection, diagnosis and treatment of mental illness. Hence, purpose of this study is to assess the knowledge and attitude on mental illness among people in a community.

\section{MATERIAL AND METHOD}

Descriptive study design was used to assess knowledge and attitude on mental illness in a community of Biratnagar. This study was conducted in ward number-3 Pokhariya, Biratnagar, Morang. Biratnagar is Metropolitan city which consists of 19 wards. Pokhari-3 is one of them consisting of 4238 household and 16002 populations. The location of research was conveniently selected. Community is place where stigma and prejudice regarding mental illness prevails and utilization of mental health services is influenced not only by the quality and availability of services but also by their knowledge and belief systems. Besides, limited study has been conducted in community level in our country context. Sample size was calculated using formula $\mathrm{Z}^{2} \mathrm{pq} / \mathrm{d}^{2}$ where $\mathrm{p}=33.3 \%$ (knowledge on mental illness $33.3 \%$ which is taken as prevalence) ${ }^{11}, \mathrm{~d}$ (allowable error $=$ $10 \%$ ). Sample size was 92 including 10\% non response rate. Sample was male and female of 21-59 years of age who were willing to participate in the study. Non- probability purposive sampling method was used to obtain information through face-to-face interview technique with semi structured questionnaire in Nepali version. Content validity of the instrument was maintained by literature review \& consulting with subject expertise. The questionnaire was translated into Nepali language by consulting with subject expert so it can relevantly use in community. A back translation was done to English language and reviewed for accuracy of the translation and finalized after consulting with experts. Pre-test was done on $10 \%$ of sample size. According to findings of the pre-test the modification was done.

Questionnaire was divided into 3 distinct parts. Part I: Socio-demographic information, Part II: Knowledge towards Mental illness and Part III: Attitude towards Mental illness. Altogether there are 35 questions in which 10 questions are related to knowledge on mental illness and all of them are multiple response questions. Each correct response carries 1 mark. The total score on knowledge is 19 and interpreted as adequate knowledge: more than or equal to median i.e., $\geq$ 9.5 and Inadequate knowledge: less than median i.e., <9.5. Similarly, likert scale is used to measure attitude. There were 22 questions related to attitude on mental illness in which 14 items reflect positive statement and 8 items reflect negative statement toward mental illness. Each attitude related question carries 5 maximum score. Total minimum score is 22 whereas maximum score is 110 and interpreted as positive attitude: more than or equal to $50 \%$. Negative attitude: less than $50 \%$.

Prior to data collection approval was taken from Research management Committee of Nursing Campus, Biratnagar, reference n. 398/073/074. Permission was taken from the related authority of Ward no. 3; reference no. 531/7/26. Written informed consent was taken from each respondent. Privacy, confidentiality of information of all the respondents was maintained. Respondent participated voluntarily and were allowed to left without any reason. Data entry and processing was done by using statistical package for social science (SPSS) "statistics for windows, version 16.0(SPSS Inc., Chicago, III.USA") after editing and coding. Descriptive statistics that is frequency and percentage mean and standard deviation was used to assess knowledge and attitude. 


\section{RESULT}

This study was conducted in 21-59 years population comprising both male and female where $48.9 \%$ were between $40-59$ years of age $51.1 \%$ were between 20 and 39 years. Among them $53.3 \%$ were male and $46.7 \%$ were female. Similarly $93.5 \%$ respondents were Hindu and $6.5 \%$ were Muslims. Likewise $81.5 \%$ were married whereas $16.3 \%$ were unmarried and only $2.2 \%$ were widow. In terms of educational status $84.8 \%$ respondents were literate whereas $15.2 \%$ respondents were illiterate. The findings shows that most of respondents $88 \%$ views mental illness as a medical condition and $85.9 \%$ views it as brain dysfunction whereas 3.3\% thinks it as a result of god's curse for past sins. In terms of cause $84.8 \%$ consider genetic recession and $2.2 \%$ views it as supernatural power. Regarding types $89.1 \%$ has stated depression and $83.7 \%$ has stated schizophrenia.

Table 1: Sociodemographic Characteristics $(\mathrm{n}=92)$

\begin{tabular}{|l|c|c|}
\hline \hline \multicolumn{1}{|c|}{ Variable } & Frequency(f) & Percentage $\%$ \\
\hline Age & & \\
\hline $20-39$ & 47 & 51.1 \\
\hline $40-59$ & 45 & 48.9 \\
\hline Sex & & \\
\hline Male & 49 & 53.3 \\
\hline Female & 43 & 46.7 \\
\hline Religion & & \\
\hline Hindu & 86 & 93.5 \\
\hline Muslim & 6 & 6.5 \\
\hline Marital status & & \\
\hline Married & 75 & 81.5 \\
\hline Unmarried & 15 & 16.3 \\
\hline Widow & 2 & 2.2 \\
\hline Education & & 84.8 \\
\hline Literate & 78 & 15.2 \\
\hline Illiterate & 14 & \\
\hline
\end{tabular}

All respondents i.e.100 \% has stated irresponsible, violent nature whereas $97.8 \%$ has stated low decision making capacity as sign and symptom. Most of respondents i.e. $81.5 \%$ stated hectic lifestyle and $80.4 \%$ stated traumatic childhood as risk factors. In terms of preventive measures, all i.e. $100 \%$ has stated avoidance of hectic lifestyle and adaptation of positive lifestyle as preventive measure whereas $23.9 \%$ thinks that daily worshiping can help to prevent.
Table 2: Knowledge On mental illness ( $\mathrm{N}=92)$

\begin{tabular}{|l|c|c|}
\hline \multicolumn{1}{|c|}{ Variable } & (f) & $\begin{array}{c}\text { Percentage } \\
(\%)\end{array}$ \\
\hline Meaning of Mental illness & & \\
\hline $\begin{array}{l}\text { Medical condition which needs } \\
\text { treatment }\end{array}$ & 81 & 88 \\
\hline $\begin{array}{l}\text { Brain dysfunction or biological } \\
\text { dysfunction }\end{array}$ & 79 & 85.9 \\
\hline Gods curse for past sin & 3 & 3.3 \\
\hline Causes of mental illness & & \\
\hline Genetic recessions & 78 & 84.8 \\
\hline God's punishment for past sins & 24 & 26.1 \\
\hline Broken family/conflict in family & 20 & 21.7 \\
\hline Supernatural powers & 2 & 2.2 \\
\hline Types of mental illness & 82 & 89.1 \\
\hline Depression & 77 & 83.7 \\
\hline Schizophrenia & 26 & 28.3 \\
\hline Bipolar disorder & & \\
\hline $\begin{array}{l}\text { Sign and symptoms of mental } \\
\text { illness }\end{array}$ & 92 & 100 \\
\hline $\begin{array}{l}\text { Cannot held responsibility for his or } \\
\text { her own actions }\end{array}$ & 92 & 100 \\
\hline Prone to violent & 90 & 97.8 \\
\hline $\begin{array}{l}\text { Unable to make simple decisions for } \\
\text { themselves }\end{array}$ & 90 & 79.3 \\
\hline Split personality & & \\
\hline Serious bouts of depression & 93.5 \\
\hline
\end{tabular}

Table 3: Knowledge on Risk factors and Preventive measures of Mental illness ( $n=92)$

\begin{tabular}{|l|c|c|}
\hline \multicolumn{1}{|c|}{ Variables } & $\begin{array}{c}\text { Frequency } \\
\text { (f) }\end{array}$ & $\begin{array}{c}\text { Percentage } \\
(\mathbf{\%})\end{array}$ \\
\hline Risk factors for mental illness & & 88 \\
\hline $\begin{array}{l}\text { Being sad and unhappy most } \\
\text { of the time }\end{array}$ & 81 & 81.5 \\
\hline Busy and hectic lifestyle & 75 & 81.5 \\
\hline Failing a romantic relationship & 75 & 80.4 \\
\hline Traumatic childhood & 74 & \\
\hline $\begin{array}{l}\text { Preventive measures of Mental } \\
\text { illness }\end{array}$ & & 100 \\
\hline $\begin{array}{l}\text { Avoid stressful and hectic } \\
\text { lifestyle }\end{array}$ & 92 & 100 \\
\hline Adaptation of positive lifestyle & 92 & 72.8 \\
\hline Avoid excessive alcohol & 67 & 23.9 \\
\hline Daily worshiping & 22 & \\
\hline
\end{tabular}

Regarding treatment, all i.e.100\% respondents has declared that long duration for treatment needed and they all seek psychiatrist for $1^{\text {st }}$ visit whereas $20.7 \%$ also seek traditional healer. Most of them i.e.66.7\% has stated that regular 
Table 4: Knowledge on treatment of mental illness ( $n=92)$

\begin{tabular}{|l|c|c|}
\hline \multicolumn{1}{|c|}{ Variables } & Frequency (f) & Percentage (\%) \\
\hline \hline Long duration needed for treatment & & \\
\hline Yes & 92 & 100 \\
\hline First contact for help & 92 & 100 \\
\hline Psychiatrist & 50 & 54.3 \\
\hline Stress reduction programs & 19 & 20.7 \\
\hline Traditional healer & 2 & 2.2 \\
\hline Medical practitioner & & \\
\hline Opinion on treating mental illness & 61 & 66.7 \\
\hline Can be treated with regular treatment and follow-up & 44 & 47.8 \\
\hline Can never be cured & 25 & 27.2 \\
\hline Reoccur despite of treatment & & \\
\hline Your reaction on seeing mentally ill people & 59 & 64.7 \\
\hline Refer to traditional healer & 19 & 20.7 \\
\hline Restrain them & 16 & 17.4 \\
\hline Marriage can treat mental illness & 14 & 15.2 \\
\hline Keep them away from home or society & & \\
\hline
\end{tabular}

Table 5: Attitude on mental illness ( $\mathrm{n}=92)$

\begin{tabular}{|l|c|c|c|c|c|}
\hline \hline Variables & SA f(\%) & $\mathbf{A f ( \% )}$ & $\begin{array}{c}\mathbf{N} \\
\mathbf{f}(\%)\end{array}$ & $\mathbf{D ~ f ( \% )}$ & $\begin{array}{c}\text { SD } \\
\mathbf{f}(\%)\end{array}$ \\
\hline $\begin{array}{l}\text { Mental health facilities in a society downgrades the } \\
\text { prestige }\end{array}$ & $1(1.1)$ & - & - & $53(57.6)$ & $38(41.3)$ \\
\hline Mentally ill people living in neighborhood is frightening & $1(1.1)$ & $31(33.7)$ & $6(6.5)$ & $42(45.7)$ & $1(1.1)$ \\
\hline $\begin{array}{l}\text { Not want to live next door to someone who has been } \\
\text { Mentally ill }\end{array}$ & $16(17.6)$ & $23(25)$ & - & $52(56.5)$ & $1(1.1)$ \\
\hline $\begin{array}{l}\text { In spite of full recovery it is foolish to get married with } \\
\text { them }\end{array}$ & $44(47.8)$ & $25(27.2)$ & - & $22(23.9)$ & $1(1.1)$ \\
\hline They are burden for our society & $22(23.9)$ & $26(28.3)$ & - & $43(46.7)$ & $1(1.1)$ \\
\hline They should not assign any responsibilities & $2(2.2)$ & $20(21.7)$ & - & $66(71.7)$ & $4(4.3)$ \\
\hline Spending on mental health is waste of money & $1(1.1)$ & $11(12)$ & $8(8.7)$ & $61(66.3)$ & $11(12)$ \\
\hline They don't deserve our sympathy & $5(5.4)$ & $32(34.8)$ & $1(1.1)$ & $41(44.6)$ & $13(14.1)$ \\
\hline
\end{tabular}

$S A=$ Strongly Agree, $A=$ Agree, $N=$ Neutral, $D=$ Disagree, $S D=$ Strongly Disagree

Table 6: Attitude on Mental illness ( $n=92)$

\begin{tabular}{|l|l|l|l|l|l|}
\hline \hline Variables & $\begin{array}{l}\mathbf{S A} \\
\mathbf{f}(\mathbf{\%})\end{array}$ & $\begin{array}{l}\mathbf{A} \mathbf{f}(\mathbf{0}) \\
\mathbf{f}(\mathbf{f})\end{array}$ & $\begin{array}{l}\mathbf{D} \\
\mathbf{f}(\mathbf{0})\end{array}$ & $\begin{array}{l}\text { SD } \\
\mathbf{f}(\mathbf{\%})\end{array}$ \\
\hline Need to adapt far more tolerant attitude towards them & $13(14.1)$ & $66(71.7)$ & $8(8.7)$ & $5(5.4)$ & - \\
\hline Mental health services should be based on community & - & $63(68.5)$ & $29(31.5)$ & - & - \\
\hline They are less dangerous than most people suppose & - & $68(73.9)$ & - & $22(23.9)$ & $2(2.2)$ \\
\hline Treating them as a part of society is effective & $30(32.6)$ & $51(55.4)$ & $3(3.3)$ & $7(7.6)$ & $1(1.1)$ \\
\hline $\begin{array}{l}\text { Should not get fear from them receiving mental health service in our } \\
\text { neighbourhood }\end{array}$ & $9(9.8)$ & $82(89.1)$ & - & - & $1(1.1)$ \\
\hline They can be trusted as babysitters after recovery & & & & & \\
\hline It is an illness like any other & $16(17.4)$ & $12(13)$ & - & $43(46.7)$ & $21(22.8)$ \\
\hline No one has right to exclude them from our society & $17(18.5)$ & $34(37)$ & $2(2.2)$ & $37(40.2)$ & $2(2.2)$ \\
\hline Mental hospitals are outdated means of treating mental illness & $86(93.5)$ & $6(6.5)$ & - & - & - \\
\hline Lack of self discipline and will power are one of the cause & $2(2.2)$ & $65(70.7)$ & $4(4.3)$ & $20(21.7)$ & $5(5.4)$ \\
\hline It's easy to recognise them because they are different & $2(2.2)$ & $83(90.2)$ & - & $2(2.2)$ & $5(5.4)$ \\
\hline As soon as person shows signs, he/she should be hospitalized & $92(100)$ & - & - & - & - \\
\hline Virtually anyone can become mentally ill & $39(42.4)$ & $42(45.7)$ & - & $11(12)$ & - \\
\hline They should have equal rights to a job as others & $46(50)$ & $46(50)$ & - & - & - \\
\hline
\end{tabular}


treatment and follow-up can help in treatment whereas $47.7 \%$ stated that mental illness can never be cured. Regarding knowledge level $97.8 \%$ have adequate knowledge whereas only $2.2 \%$ have inadequate knowledge. Regarding attitude most of respondents i.e. $54.7 \%$ have negative attitude whereas 45.7 have positive attitude.

\section{DISCUSSION:}

The findings of the study showed that $51.1 \%$ respondents were from age group of 20-39 years which is contradict with the findings of study among Rural and Urban Community of Jhapa District of Nepal, with sample size 100 in which $80.7 \%$ were from age group of $20-39$ years. ${ }^{11}$ The study presented that $84.8 \%$ respondents were literate which corresponds with findings of study conducted in Urban Community in South Delhi in which $84 \%$ were literate. ${ }^{3}$ This study showed that most of respondents i.e. 53.3\% were male which is coherence with findings of study in which $54.5 \%$ were male. ${ }^{5}$

The findings of the study in terms of causes only $2.2 \%$ believes mental illness as a result of supernatural power which is contradictory with the findings of the study conducted in Delhi which states one fourth of participants perceived the role of supernatural powers as causative factor. It is contradictory because of the higher literacy rate $(84.8 \%)$ and urban residential area. ${ }^{3}$ Likewise study conducted in Dang Nepal showed that 25\% responded that physical and emotional trauma can lead to mental illness. Fear of discrimination and social stigma are seen to be the primary factors for reluctance to seek treatment. ${ }^{13}$

On the part of sign and symptoms of mental illness all participants (100\%) believes that mentally ill people cannot held responsibility for his/her own actions and are prone to be violent whereas most of respondents $97.8 \%$ believes that they are unable to make simple decisions for themselves, $79.3 \%$ participants consider split personality and almost half, $43.5 \%$ perceived serious bouts of depression as sign symptoms of mental illness. These findings of this study are similar with the findings of the study conducted in Urban Community in South Delhi which showed awareness of the community about symptoms/signs of mental illness is limited to symptoms that manifest in severe mental illness or in later stage of the illness. ${ }^{3}$ The reason could be either lack of awareness of participants about other common symptoms like sense of hopelessness, aloofness, and anxiety or may be that these symptoms are too common to be recognized as abnormal.Regarding treatment of mental illness this study showed that all participant's choice of first contact was psychiatrist which is similar to the findings of the study among General Public in Yaoundé in which $64.3 \%$ seeks psychiatrist. ${ }^{5}$

This study showed that $97.8 \%$ have adequate knowledge on mental illness which is contradictory with findings of study conducted among General Public of Southern India, in which most of the respondents have inadequate knowledge on mental illness. This shows that respondents already known about the topic as the area of study were urban community and $84.8 \%$ were literate. But $54.3 \%$ respondents had negative attitude and $45.7 \%$ had positive attitude towards mental illness which is coherence with the findings of similar study. ${ }^{12}$

Despite of having good knowledge on mental illness, almost half $(44 \%)$ of the participants think, in spite of full recovery it is foolish to get married with them. All participants consider that mentally ill people are easily recognizable because they are different from normal people, $28.3 \%$ respondents agree that they are burden for our society and $41.3 \%$ responded strongly disagree that mental health facilities in a society downgrades the prestige resembling to this study, cross sectional study conducted among general public of Southern India stated that Mentally ill people are labeled as "different" from other people and are viewed negatively by others, $54.5 \%$ agree that a person should not marry anyone who has suffering from mental illness even though he/she seems fully recovered, $10 \%$ responded burden to society. ${ }^{12}$ likewise in this study $71.7 \%$ respondents disagree that they should not assign any responsibility, $66.3 \%$ disagree that spending on mental health is waste of money where as $55.4 \%$ respondents agree that treating them a part of society is effective which is contradict with the findings of the study done in urban community of west Bengal which showed $31 \%$ disagree that they should not give any responsibility, $87.5 \%$ 
disagree that increase spending on mental health services is a waste of money and $88.5 \%$ agree that no one has the right to exclude people with mental illness from their neighbourhood. ${ }^{14}$ This contradiction might be due to difference in sample size. Many studies have demonstrated that persons labeled as mentally ill are perceived with more negative attributes and are more likely to be rejected regardless of their behavior. A persistent negative attitude and social rejection of people with mental illness has prevailed throughout history in every social and religious culture. Of all the health problems, mental illnesses are poorly understood by the general public. Health education and awareness through mass media is required to reduce stigma, prejudices and discrimination related to mental illness.

\section{CONCLUSION:}

The finding of the study suggests level of knowledge was adequate among respondents whereas most of them had negative attitude towards mental illness. The maximum level of negative attitude suggests the strong emphasis on public education to increase positive attitude towards mental illness.

ACKNOWLEDGEMENT: Researchers would like to express gratitude and thanks to Tribhuvan University, Institute of Medicine, Biratnagar Nursing Campus, for providing the opportunity to carry out this research work. The researchers wishes to extend heartfelt gratitude to VDC secretariat of ward no.3 of Biratnagar and all the respondents for their kind $\mathrm{CO}^{-}$ operation and valuable time.

\section{FUNDING: None}

\section{CONFLICT OF INTEREST: None}

\section{REFERENCES:}

1. Parekh, R. American Psychiatric Association;2015. Cited on on 29th April, 2017. Available from https://www.psychiatry.org/patientsfamilies/what-is-mental-illness

2. Psychologists Desk Reference [Internet]. The Criminal Justice Topic. The mentally insane and low enforcement[cited 2021 Sep 22].Available from: Psychologists Desk Reference | The Criminal Justice Topic (wordpress.com)
3. Salve H,Goswami K,Sagar,Nongkynri, R Perception and Attitude towards Mental Illness in an Urban Community in South Delhi - A Community Based Study [internet].cited on 29th April,2017.Available from Indian J Psychol Med. 2013, Apr;35(2):154-8. Doi: 10.4103/02537176.116244.

4. Luitel, N.P., Jordans, JD. M., Adhikari, A., Upadhaya, N., Hanlon, C., Lund,C. , and Komproe,I. Mental health care in Nepal: current situation and challenges for development of a district mental health care plan. cited on $26^{\text {th }}$ April 2017.Available from https://www.ncbi.nlm.nih.gov/pmc /articles /PMC4331482/

5. Yongsi, B.N.Knowledge and Attitudes Towards Mental Health and Mental Illness Among General Public in Yaoundé[internet]. Geospatial Land \& Health Research Group Institute for Training \& Research in Population Studies (IFORD); 2015. Cited on 26th April 2017 doi: 10.1186/s13031-0140030-5.

6. Walker, I., and Uprety, S. Mainstreaming Mental Health: Context, Challenges and critical pathways Presentation for Idea Interchange, Health Research and Social Development Forum[internet];2016, cited on $1^{\text {st }}$ May 2017.Available from https://www.herd.org.np/uploads/fronted/pub licationsAttachments1/1481709304

7. Prince M, Patel V, Saxena S, Global mental health 1 , no health without mental health. Lancet;370(9590): 859-877;2007, cited on 1st May 2017. Available from https://www.ncbi.nlm.nih.gov/pubmed/1780406 3

8. World Health Organization.10 Facts on Mental Health. Fact files; 2011.Cited on 26 th April 2017.Available from http://www.who.int/features/factfiles/mental _health/mental_health_facts/en/index4.html

9. KohrtA.B.,Harper, I., Navigating Diagnoses: Understanding Mind-Body Relations, Mental Health, and Stigma in Nepal. PubMed Central. cited on 2nd April 2017.Available from https://www.ncbi.nlm.nih.gov/pmc/articles/PM C3869091/\#R11

10. Webber, M., Corker, E., Weeks, C., Pinfold, V., Rose, D., and Henderson, C. Discrimination against people with severe mental illness and their access to social Capital: findings from the viewpoint survey[internet]. Epidemiology And Psychiatric Sciences, 23(2);2014, cited on 1'st May 2017.Available from https://www.ncbi.nlm.nih.gov/pmc/articles/PM C4165871/ 
11. Singh, B., Singh, R. and Singh, K.K. Knowledge and attitude towards mental health and mental illness: an issue among rural and urban community of Jhapa district of Nepal [internet]. International Journal Health Science Research;3(9): 29-34;2013, cited on 28 April 2017.Available from http:/ / www.scopemed.org/?mno=45096

12. Ganesh, K. (2011); Knowledge and attitude of mental illness among general public of Southern India[internet]. National journal of Community Medicine;2(1): 175-178: 2011, cited on 26 April 2017. Available from http://njcmindia.org/uploads/2-1_175-178.pdf

13. Das, R., Adhikari, P. and Sharma, B. Knowledge, Attitude and Practice Survey of Community People Regarding Mental Illness: Evidence from Dang District of Nepal[internet]. Journal of Young Medical Researcher,1(1): 2014, cited on April 26, $2017 . \quad$ Available from http://jymr.in/index.php/jymr/article/view/5

14. Basu R, Sau A, Saha S, Mondal S, Ghoshal PK, Kundu S. A study on knowledge, attitude, and practice regarding mental health illnesses in Amdanga block, West Bengal. Indian J Public Health. 2017 Jul 1;61(3):169. 